\title{
Editorial for Special Issue "Applications of SEM Automated Mineralogy: From Ore Deposits over Processing to Secondary Resource Characterization"
}

\author{
Bernhard Schulz \\ Institute of Mineralogy, Economic Geology and Petrology, TU Bergakademie Freiberg, Brennhausgasse 14, \\ D-09599 Freiberg/Saxony, Germany; bernhard.schulz@mineral.tu-freiberg.de; Tel.: +49-3731-39-2668
}

Received: 29 November 2020; Accepted: 4 December 2020; Published: 9 December 2020

\section{Introduction}

Matter is particulate. Grains, particles and their compounds are fundamental constituents of many important materials in nature and technology. During the last decade, software developments in scanning electron microscopy (SEM) have provoked a notable increase in applications to the study of solid matter. The mineral liberation analysis (MLA) of processed metal ores was an important driver for innovations that led to several software platforms. These combine the assessment and analysis of the backscattered electron (BSE) image to the directed steering of the electron beam for energy dispersive spectroscopy (EDS) to automated mineralogy [1-6]. However, despite a wide distribution of SEM instruments in material research and industry, the potential of SEM automated mineralogy (SEM-AM) is still under-utilised. The MDPI with the journal Minerals generously provides a versatile platform to bring articles dealing with SEM-AM applications to a widespread audience in applied and basic research. The Minerals Special Issue Applications of SEM Automated Mineralogy: From Ore Deposits over Processing to Secondary Resource Characterization is one of the publications dedicated to this goal.

A bulk material (rock, ore) chemical analysis provides no specific information on the target element-bearing phases (ore minerals) - a crystallographic analysis by X-ray diffraction (XRD) will identify the target phase (ore mineral) if its mode is $>1 \mathrm{wt} \%$, but gives no target particle size information-sedimentological particle size analysis allows no distinction among the numerous phases (gangue and ore minerals) in compounds-and, studies by optical microscopy are time-intensive, hardly deliver statistically sound databases, and are affected by subjective bias. The demands of the mineral industry and of mineral processing were the main driving forces to overcome the methodological limits and gaps of these single, well-established and validated analytical methods. Specific analytical questions related to the identification of phases (ore minerals) and characterization of grain and particle properties are common to all disciplines and stages along the raw materials processing chain, from geoscientific exploration to mining, through flotation and concentration to metallurgy up to tailing deposition and potential environmental hazards [7-9]. An answer to the challenges is the development of SEM-AM, an analytical tool combining software for BSE image examination, with more important specific steering control of the electron beam for EDS spectral analyses. Different classification algorithms and four principal SEM-AM measurement routines for point counting modal analysis, particle analysis, sparse phase search and EDS spectral mapping are offered by the relevant software providers [1,10-12]. These measurement routines provide the potential for the SEM-AM applications to scientific topics outside of the raw materials processing chain [13-18].

\section{The Special Issue}

This Special Issue contains ten papers which cover a wide spectrum of SEM-AM case histories and innovative applications. The characterization of primary ores, and the optimisation of comminution, 
flotation, mineral concentration and metallurgical processes in the mining industry by generating quantified data, is still the major field of application for SEM-AM. An article by Gronen et al. [19] on $\mathrm{Zr}$-REE- $\mathrm{Nb}$ ores from alkaline granitoids in Mongolia addresses the problem of post-magmatic alteration causing fine and intricate intergrowth of the ore minerals with associated gangue. This hampers the economic recovery of this deposit type, as intensive comminution is necessary to liberate the ore minerals. Automated mineralogy was applied to quantify the textural properties of the ore phases which occur in mineral clusters. The analytical results permit an efficient pre-concentration of rare metal ores at coarser particle size fractions, requiring less energy consumption during comminution.

An article by Warlo et al. [20] deals with a novel approach to overcome difficulties when trace minerals are detected within a single measurement when they are accompanied by the major ore minerals. Small grain sizes of the trace minerals complicate the task as they induce mixed X-ray signals.

The contribution of generically labelled EDS spectra in the mineral processing of rare earth element ores by Schulz et al. [21] provides a possibility for how to relate the EDS spectra from the complex and variable REE mineral phases in an ore to mineral names. The labelling of the spectra obtained from REE-bearing minerals is based on their contents of $\mathrm{Si}, \mathrm{Ca}, \mathrm{F}$ and $\mathrm{P}$ in a bulk normalised analysis. The labelled spectra are then combined into groups of REE-P ( monazite), REE-Ca-Si-P ( britholite), REE-Ca-F ( synchysite) and REE-F ( bastnaesite, parisite, fluocerite) and a mixed spectra group with low counts for REE. This classification scheme is applied in several case studies with SEM-AM data from beneficiation products by comminution and multistage flotation of REE carbonatite ores.

Iron ores require specific methodological solutions when analysed by SEM-AM as is outlined in the article by Krolop et al. [22]. Similar elemental compositions of hematite and magnetite and almost identical backscattered electron (BSE) intensities complicate their discrimination in compound ores. Raman imaging is applied and compared to the EDS spectral mapping data for control and the improvement of classification, iron ore discrimination and measurement time duration.

SEM-AM facilitates studies that are not feasible with other methods. This is exemplified in the article by Lougheed et al. [23] on the base metal exploration using heavy mineral concentrates (HMC). Traditional methods rely on visual examination of HMC fractions $>250 \mu \mathrm{m}$, but SEM-AM allows to investigate the finer fractions $(<250 \mu \mathrm{m})$ as encountered in glacial till samples. Precise compositional and morphological data from a large number $(10,000-100,000)$ of heavy mineral grains in a single sample can be collected, and rare specific indicator minerals can be reliably identified.

One motivation for the production of this Special Issue is to demonstrate the potential of SEM-AM beyond its classical field of applications in mining and mineral processing. The contribution by Keulen et al. [24] is entitled "Automated Quantitative Mineralogy Applied to Metamorphic Rocks" and deals with the application of the comparably new ZEISS Mineralogic software platform (Carl Zeiss Microscopy Ltd., Cambridge, UK) to petrological investigations of complete $25 \times 45 \mathrm{~mm}$ sized petrographic thin sections. A direct quantification of the EDS spectra allows for the visualisation of element zonations in garnet and other minerals, and for detailed recognition of metamorphic textures. In this way, mineral maps, element concentration maps, element ratio maps and mineral association maps can be produced. Additionally, the conventional mineral modes, grain shapes, sizes, and orientations can be recognised at a quantitative level.

A paper by Graham and Keulen [25] amplifies the SEM-AM applications in petrology to the special rock type of a fault gouge. Such rocks are hard to investigate by conventional methods. Additionally, the EDS spectral analysis of the extreme fine grain sizes at the submicrometer scale in such rocks is hampered by the large interaction volume of the primary electron beam which leads to mixed signals. By applying a low primary beam acceleration voltage, combined with a large aperture, and a dedicated mineral classification, these mixed signals can be deconvoluted down to a grain size of $200 \mathrm{~nm}$. This allowed the authors to obtain reliable quantitative mineralogy and grain size distribution data from the rocks by SEM-AM.

Recycling technology and secondary resources from waste treatment are emergent fields which require adopted analytical methods for phase identification, as well as grain and particle characterization. 
This topic is addressed by a paper from Buchmann et al. [26] entitled "Evaluation of Recyclability of a WEEE Slag by Means of Integrative X-Ray Computer Tomography and SEM-Based Image Analysis". Waste of electrical and electronic equipment (WEEE) contains a lot of metals and rare earth elements. Smelting of WEEE leads to significant trapping of such elements in slags from which they are hard to extract again. To make recycling economically applicable it is crucial to bring these metal contents into deducible structures. The technical manipulation of the phase transfer processes necessitates detailed understanding and controls. Therefore, WEEE slag is investigated by X-ray computed tomography (XCT) and SEM-AM to understand the typical structures and their implications for further processing and extraction.

Ashes resulting from technical processes such as combustion in power plants are increasingly considered as secondary resources. This especially applies for sewage slush ashes which are a potential resource for phosphorus. Conventionally, a great deal of ash is analysed by X-ray diffraction (XRD) and Rietveld methods for phase identification and modal composition. However, as in slags, a considerable part of the ash is made up by amorphous or glassy particles, of which, sorts and sizes cannot be satisfactorily characterised by XRD and sedimentological grain size classification. A novel analytical approach to this topic is presented by Guhl et al. [27] in a contribution entitled "An Improved Evaluation Strategy for Ash Analysis Using SEM-AM". Sewage slush ashes are materials composed of polyphase particles. For the establishment of a recycling process, the characterization of the phosphorus-bearing particles with heterogeneous compositions is of major interest. This can be performed by EDS spectral mapping involving spectra classification and grouping related to the phosphorus-bearing target components.

The contributions to this Special Issue are restricted to a given time period. Additionally, manuscripts where SEM-AM is applied along with other analytical methods may be identified as contributions to more specialised topics. For the presentation of the potential of SEM-AM to a broader audience, a review contribution is needed. That is provided by Schulz et al. [12], entitled "SEM-Based Automated Mineralogy and its Application in Geo- and Material Sciences". It presents an overview of the SEM-AM measurement routines and their implementation in the available software platforms. The different EDS spectra classification algorithms, the pitfalls of spectra labelling and the often neglected challenges of sample preparation, are discussed. As demonstrated by case examples in this contribution, the EDS spectral mapping methods appear to have the most promising potential for novel applications in metamorphic, igneous and sedimentary petrology, ore fingerprinting, ash particle analysis, characterization of slags, forensic sciences, archaeometry and investigations of stoneware and ceramics.

\section{Summary and Outlook}

This Special Issue presents the view that SEM-AM allows for a wide spectrum of targeted studies on solid and particulate matter beyond its initial and traditional applications in the mining industry and process mineralogy. However, even though SEM instruments are widespread in various public, governmental and commercial research institutions, only a very limited number of working groups operate and have access to SEM-AM equipment. In Germany, this equates to only three working groups-two at universities and one at a federal geological survey institution. A similar situation can be found in other European countries, and indeed, worldwide. In Germany one university group is located at the RWTH Aachen. The other group is situated at Freiberg/Saxony, as an association between TU Bergakademie and the Helmholtz Institute Freiberg for Resource Technology. Members of these groups, among others, contributed various articles to this Special Issue. This is no coincidence, as both locations are well-known for base and applied research in all kinds of mineral resources and process mineralogy. Hopefully, the reports and case studies in this Special Issue will encourage further working groups in geo and material sciences to invest in corresponding SEM upgrades for automated mineralogy for the investigation of exciting new application fields. 
Funding: This research was funded by the Helmholtz Institute Freiberg for Resource Technology, the Deutsche Forschungsgemeinschaft (DFG) Grant SCHU676/20 and through contract work for numerous enterprises. The Open Access Funding and APC was funded by the Publication Fund of the TU Bergakademie Freiberg.

Acknowledgments: The Guest Editor would like to sincerely thank all authors, reviewers, the editor Francis Wu and the editorial staff of Minerals for their timely efforts to successfully complete this Special Issue.

Conflicts of Interest: The author declares no conflict of interest.

\section{References}

1. Gottlieb, P.; Wilkie, G.; Sutherland, D.; Ho-Tun, E.; Suthers, S.; Perera, K.; Jenkins, B.; Spencer, S.; Butcher, A.; Rayner, J. Using quantitative electron microscopy for process mineralogy applications. JOM 2000, 52, 24-25. [CrossRef]

2. Gu, Y. Automated scanning electron microscope based mineral liberation analysis. An introduction to JKMRC/FEI Mineral Liberation Analyser. J. Miner. Mater. Charact. Eng. 2003, 2, 33-41. [CrossRef]

3. Lastra, R. Seven practical application cases of liberation analysis. Int. J. Miner. Process. 2007, 84, 337-347. [CrossRef]

4. Fandrich, R.; Gu, Y.; Burrows, D.; Moeller, K. Modern SEM-based mineral liberation analysis. Int. J. Miner. Process. 2007, 84, 310-320. [CrossRef]

5. Hoal, K.O.; Stammer, J.G.; Appleby, S.K.; Botha, J.; Ross, J.K.; Botha, P.W. Research in quantitative mineralogy: Examples from diverse applications. Miner. Eng. 2009, 22, 402-408. [CrossRef]

6. Sylvester, P. Use of the Mineral Liberation Analyzer (MLA) for Mineralogical Studies of Sediments and Sedimentary Rocks. In Quantitative Mineralogy and Microanalysis of Sediments and Sedimentary Rocks; Sylvester, P., Ed.; Mineralogical Association of Canada (MAC): St. John's, NL, Canada, 2012; Volume 42, pp. 1-16.

7. Gäbler, H.-E.; Melcher, F.; Graupner, T.; Bähr, A.; Sitnikova, M.A.; Henjes-Kunst, F.; Oberthür, T.; Brätz, H.; Gerdes, A. Speeding Up the Analytical Workflow for Coltan Fingerprinting by an Integrated Mineral Liberation Analysis/LA-ICP-MS Approach. Geostand. Geoanal. Res. 2011, 35, 431-448. [CrossRef]

8. Lund, C.; Lamberg, P.; Lindberg, T. Practical way to quantify minerals from chemical assays at Malmberget iron ore operations-An important tool for the geometallurgical program. Miner. Eng. 2013, 49, 7-16. [CrossRef]

9. Mariano, R.A.; Evans, C.L. Error analysis in ore particle composition distribution measurements. Miner. Eng. 2015, 82, 36-44. [CrossRef]

10. Graham, S.D.; Brough, C.; Cropp, A. An Introduction to ZEISS Mineralogic Mining and the Correlation of Light Microscopy with Automated Mineralogy: A Case Study using BMS and PGM Analysis of Samples from a PGE-bearing Chromite Prospect. In Proceedings of the Precious Metal Conference, Vienna, Austria, 18-20 October 2015; pp. 1-12.

11. Hrstka, T.; Gottlieb, P.; Skála, R.; Breiter, K.; Motl, D. Automated Mineralogy and Petrology-Applications of TESCAN Integrated Mineral Analyzer (TIMA). J. Geosci. 2018, 63, 47-63. [CrossRef]

12. Schulz, B.; Sandmann, D.; Gilbricht, S. SEM-Based Automated Mineralogy and its Application in Geo- and Material Sciences. Minerals 2020, 10, 1004. [CrossRef]

13. Pirrie, D.; Butcher, A.R.; Power, M.R.; Gottlieb, P.; Miller, G.L. Rapid quantitative mineral and phase analysis using automated scanning electron microscopy (QemSCAN); potential applications in forensic geoscience. Geol. Soc. London Spec. Publ. 2004, 232, 123-136. [CrossRef]

14. Knappett, C.; Pirrie, D.; Power, M.R.; Nikolakopoulou, I.; Hilditch, J.; Rollinson, G.K. Mineralogical analysis and provenancing of ancient ceramics using automated SEM-EDS analysis (QEMSCAN ${ }^{\circledR}$ ): A pilot study on LB I pottery from Akrotiri, Thera. J. Archaeol. Sci. 2011, 38, 219-232. [CrossRef]

15. Von Eynatten, H.; Tolosana-Delgado, R.; Karius, V.; Bachmann, K.; Caracciolo, L. Sediment generation in humid Mediterranean setting: Grain-size and source-rock control on sediment geochemistry and mineralogy (Sila Massif, Calabria). Sediment. Geol. 2016, 336, 68-80. [CrossRef]

16. Pietranik, A.; Kierczak, J.; Tyszka, R.; Schulz, B. Understanding heterogeneity of a slag-derived weathered material: The role of automated SEM-EDS analyses. Minerals 2018, 8, 513. [CrossRef]

17. Pirrie, D.; Crean, D.E.; Pidduck, A.J.; Nicholls, T.M.; Awbery, R.P.; Shail, R.K. Automated mineralogical profiling of soils as an indicator of local bedrock lithology: A tool for predictive forensic geolocation. Geol. Soc. London Spec. Pub. 2019, 492. [CrossRef] 
18. Minde, M.W.; Zimmermann, U.; Madland, M.V.; Korsnes, R.I.; Schulz, B.; Gilbricht, S. Mineral replacement in long-term flooded porous carbonate rocks. Geochim. Cosmochim. Acta 2020, 268, 485-508. [CrossRef]

19. Gronen, L.H.; Sindern, S.; Katzmarzyk, J.L.; Bormann, U.; Hellmann, A.; Wotruba, H.; Meyer, F.M. Mineralogical and Chemical Characterization of Zr-REE-Nb Ores from Khalzan Buregtei (Mongolia)—Approaches to More Effcient Extraction of Rare Metals from Alkaline Granitoids. Minerals 2019, 9, 217. [CrossRef]

20. Warlo, M.; Wanhainen, C.; Bark, G.; Butcher, A.R.; McElroy, I.; Brising, D.; Rollinson, G.K. Automated Quantitative Mineralogy Optimized for Simultaneous Detection of (Precious/Critical) Rare Metals and Base Metals in A Production-Focused Environment. Minerals 2019, 9, 440. [CrossRef]

21. Schulz, B.; Merker, G.; Gutzmer, J. Automated SEM Mineral Liberation Analysis (MLA) with Generically Labelled EDX Spectra in the Mineral Processing of Rare Earth Element Ores. Minerals 2019, 9, 527. [CrossRef]

22. Krolop, P.; Jantschke, A.; Gilbricht, S.; Niiranen, K.; Seifert, T. Mineralogical Imaging for Characterization of the Per Geijer Apatite Iron Ores in the Kiruna District, Northern Sweden: A Comparative Study of Mineral Liberation Analysis and Raman Imaging. Minerals 2019, 9, 544. [CrossRef]

23. Lougheed, H.D.; McClenaghan, M.B.; Layton-Matthews, D.; Leybourne, M. Exploration Potential of Fine-Fraction Heavy Mineral Concentrates from Till Using Automated Mineralogy: A Case Study from the Izok Lake $\mathrm{Cu}-\mathrm{Zn}-\mathrm{Pb}-\mathrm{Ag}$ VMS Deposit, Nunavut, Canada. Minerals 2020, 10, 310. [CrossRef]

24. Keulen, N.; Malkki, S.N.; Graham, S. Automated Quantitative Mineralogy Applied to Metamorphic Rocks. Minerals 2020, 10, 47. [CrossRef]

25. Graham, S.; Keulen, N. Nanoscale Automated Quantitative Mineralogy: A 200-nm Quantitative Mineralogy Assessment of Fault Gouge Using Mineralogic. Minerals 2019, 9, 665. [CrossRef]

26. Buchmann, M.; Borowski, N.; Leißner, T.; Heinig, T.; Reuter, M.A.; Friedrich, B.; Peuker, U.A. Evaluation of Recyclability of a WEEE Slag by Means of Integrative X-Ray Computer Tomography and SEM-Based Image Analysis. Minerals 2020, 10, 309. [CrossRef]

27. Guhl, A.C.; Greb, V.-G.; Schulz, B.; Bertau, M. An improved evaluation strategy for ash analysis using scanning electron microscope automated mineralogy. Minerals 2020, 10, 484. [CrossRef]

Publisher's Note: MDPI stays neutral with regard to jurisdictional claims in published maps and institutional affiliations.

(C) 2020 by the author. Licensee MDPI, Basel, Switzerland. This article is an open access article distributed under the terms and conditions of the Creative Commons Attribution (CC BY) license (http://creativecommons.org/licenses/by/4.0/). 